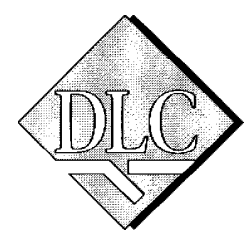

\title{
Evolution of the Palaeoproterozoic Nagssugtoqidian orogen: DLC investigations in West Greenland
}

\author{
Mogens Marker, Flemming Mengel, \\ Jeroen van Gool and field party
}

During the summer of 1994, the Danish Lithosphere Centre (DLC) initiated geological field investigations of the Nagssugtoqidian orogen in West Greenland as part of a project on the architecture and dynamics of Palaeoproterozoic orogens. The 1994 field work was the first of three field campaigns in the Nagssugtoqidian orogen that have been planned for 1994, 1995 and 1997.

The Nagssugtoqidian orogen in West Greenland is the central segment of a trans-Atlantic Palaeoproterozoic collisional orogen that extends from the northern Baltic Shield in north-west Europe over South-East and SouthWest Greenland to Labrador in Canada. This orogenic zone occurs along the northern margin of the North Atlantic Archaean craton, and involves in all segments extensive reworking of Archaean crust during Palaeoproterozoic accretion. While the European and Canadian segments of the orogen are quite well understood, the Nagssugtoqidian orogen was, despite its central position, the least well known prior to the initiation of the present DLC project. The belt is important not only because of this key position, but also because of its excellent exposure over a large area. In addition, the Nagssugtoqidian belt is located close to the oldest crust on Earth - the 3.9 Ga Isua complex - and, if relevant, the study can be extended to incorporate preNagssugtoqidian crustal evolution. The present DLC studies are aimed at investigating Palaeoproterozoic crustal accretion, evolution and processes based on a comprehensive study of the Nagssugtoqidian orogen, and at describing, constraining and modelling the correlation of Proterozoic orogens across the North Atlantic.

\section{Logistic framework}

The 1994 field work was carried out in July and August in the region between Evighedsfjord $\left(66^{\circ} \mathrm{N}\right)$ and Disko Bugt $\left(69^{\circ} \mathrm{N}\right.$; Fig. 1). The extensive network of inlets and fjords provides easy access to large parts of the orogen. The town Sisimiut served as the logistic centre throughout the summer. Transport in the area was mainly by boat, and rubber boats for work on coastal exposures, while helicopters provided transport for inland camp moves and reconnaissance.

\section{Subdivision of the Nagssugtoqidian orogen}

Compilations of existing regional geological data (e.g. Escher, 1971; Allaart, 1982; Olesen et al., 1979), stream sediment geochemical data (e.g. Steenfelt et al., 1993) and aeromagnetic data (Thorning, 1984, 1993, unpublished data) permit a division of the Nagssugtoqidian orogen into southern (SNO), central (CNO) and northern (NNO) segments (Fig. 1). The SNO, intruded by the $c .2 .0 \mathrm{Ga}$ old Kangâmiut dyke swarm, generally in amphibolite facies, represents the variably reworked southern Archaean foreland which is in tectonic contact with the non-reworked granulite facies Archaean foreland to the south. This contact is known as the southern Nagssugtoqidian front (Escher et al., 1970, 1975). The NNO represents the variably deformed northern Nagssugtoqidian foreland (Archaean) which constitutes the poorly constrained link with the Palaeoproterozoic Rinkian Belt further north in the Disko Bugt area (e.g. Grocott \& Pulvertaft, 1990). The CNO forms the core of the orogen within which one or more collisional sutures are likely to be located. The CNO comprises two parts: a southern, highly deformed granulite facies part with a linear magnetic signature and a consistently steep to moderately $\mathrm{N}$-dipping fabric, and a northern part containing structures with a sub-horizontal enveloping surface characterised by mainly upright, open large-scale folds reflected in the magnetic pattern. The northern part of the $\mathrm{CNO}$ consists of Archaean gneisses in amphibolite facies in the east and granulite facies in the west. These are overlain by Palaeoproterozoic, marblebearing supracrustal rocks, structurally underlying voluminous, c. $1.92 \mathrm{Ga}$ quartz diorites that geochemically show island arc affinity (Kalsbeek et al., 1987). The CNO is separated from the NNO by a major steep belt described from earlier studies as the crustal scale Nordre Strømfjord shear zone (Bak et al., 1975a, b; Sørensen, 1983).

\section{The present study}

The subdivision of the Nagssugtoqidian orogen described above proved to be an excellent framework for the present investigations. The work in 1994 was concentrated in the $\mathrm{CNO}$ and $\mathrm{SNO}$, while the $\mathrm{NNO}$ was investigated on 


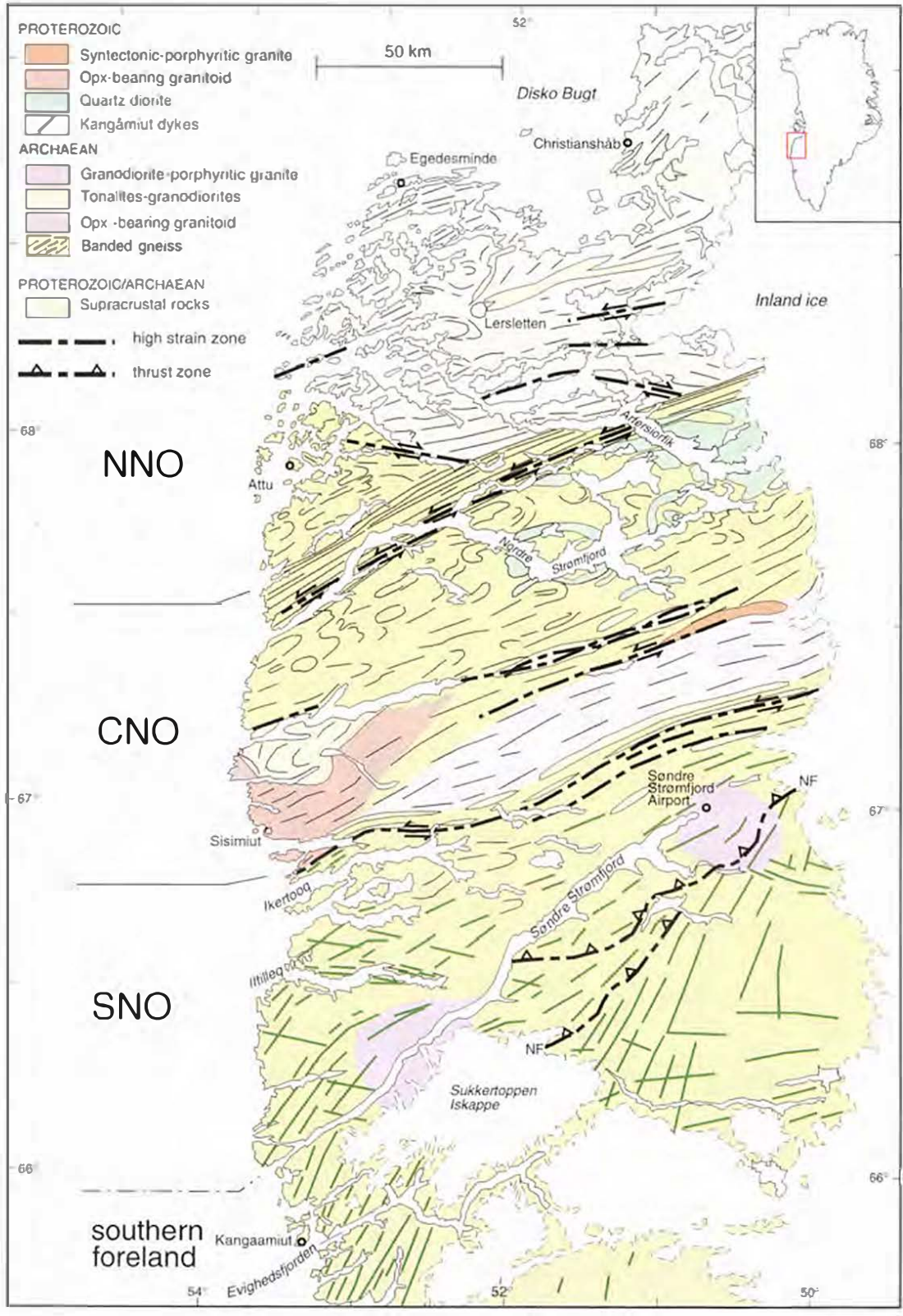

Fig. I. Sketch map of the Nagssugtoçidian orogen. showing the main lithological and tectonic units. NNO, CNO and SNO are the northern. central and southern subdivi. sions of the Nagssugtogidian orogen. respectively. a reconnaissance level. The field work was carried out by an international team of 16 geologists representing a wide range of geological expertise within structural, metamorphic and regional geology. geochronology. geochemistry and isofope chemistry. Detailed field work in selected key areas was combined with geological reconnaissance studies and collection of selected samples for petrological. geochemical, geochronological, metamorphic and microstructural studies.

Field work included characterisation of the various rock units and their relations, mapping of structures at different scales and collection of thousands of structural measurements. Of particular importance was the description of the major crustal boundaries and the documentation of shear zones and movement directions by a careful study of kinematic shear sense indicators. Geochronological programmes in progress have been set up to calibrate the relative sequence of events established during field work and to constrain the age of orogenic evolution.

\section{Results}

The wealsh of new field data from the 1994 season and the metamorphic and geochronological analytical work in progress have already significantly revised the previous view of the Nagssugtoqidian orogen. On the geochrono- 


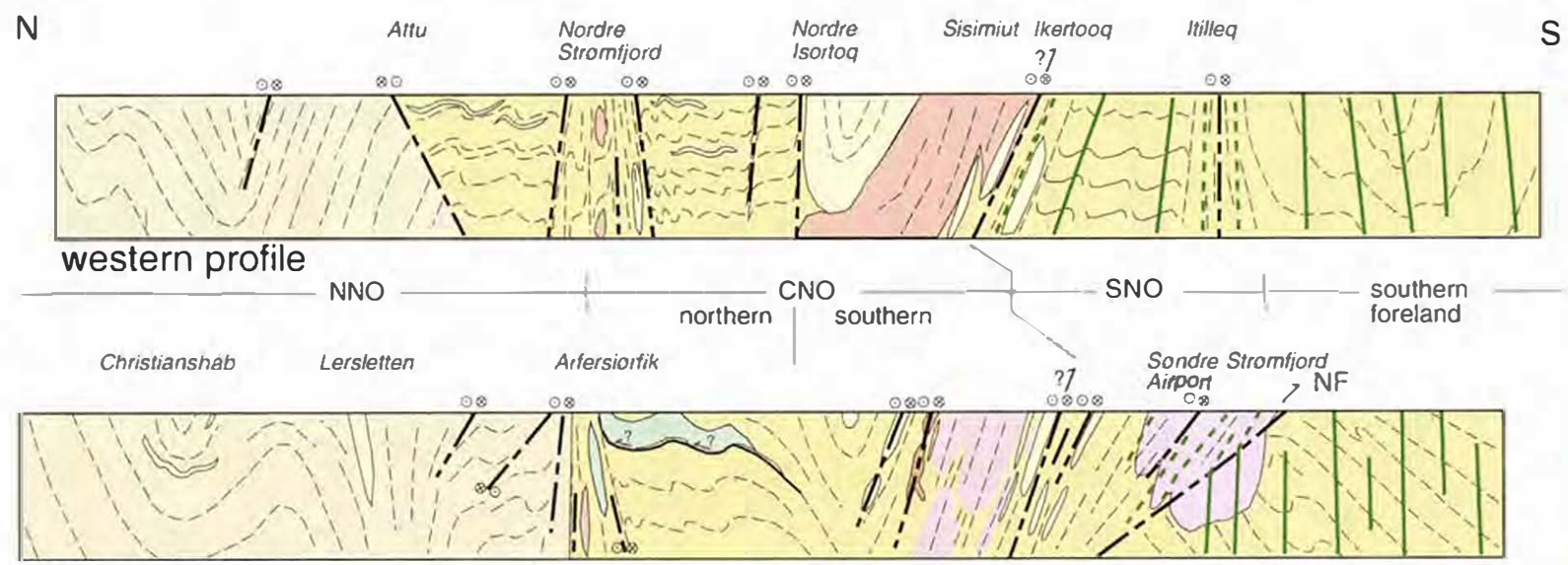

eastern profile

PROTEROZOIC

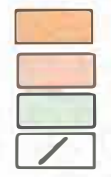

Syntectonic porphyritic granite Opx-bearing granitoids Quartz diorite Kangâmiut dykes PROTEROZOIC/ARCHAEAN $\square$ Supracrustal rocks

\section{ARCHAEAN}

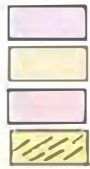

Granodiorite/porphyritic granite Tonalite to granodiorite Opx-bearing granitoids Banded gneiss

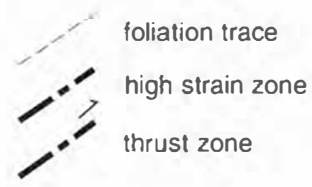

$50 \mathrm{~km}$

Fig. 2. Schematic N-S cross-sections from c. $69^{\circ} \mathrm{N} 1066^{\circ} \mathrm{N}$. showing the main structures, lithologies and subdivisions of the Nagssugtoqidian orogeny.

logical side. programmes have been established to date various stages of the orogenic evolution using primarily U-Ph dating of zircons by conventional (J. Connelly) and ion-probe (SHRIMP. A. Nutman) methods, and also by using the Sm-Nd system (M. Whitehouse). Since only limited age information was available from previous investigations of the Nagssugtogidian orogen, a SHRIMP U-Ph zircon reconnaissance programme was carried out at the Australian National University in Canberra in order to obtain a large number of approximate ages from the whole orogen (F. Kalsbeek and A. Nutman). About 9() samples were selected for this study, and 3-4 zircons were analysed per sample. Ages quoted below are results from these studies.

The field investigations of gneisses in the SNO and the southern Archaean foreland revealed a lithological continuity between the (wo units. The SNO represents the parautochehonous southern Nagssugtogidian foreland bounded to the south by a tectonic zone, the Nagssugtoqidian front ( $\mathrm{NF}^{2}$ in Figs 1, 2), which marks the southern limit of Nagssugtogidian deformation. As in earlier studies (e.g. Escher et al., 197()) the c. 2.05 (ial old Kangâmiut dyke swarm (A. Nutman. umpublised data), which occurs in both the SNO and the foreland. forms an excellent marker for Nagssugtoqidian deformation, manifested by transposition of dykes into moderately to steeply NNW-dipping orientations. The southern Nagssugtogidian front appears to form the southernmost expression of a network of discontinuous zones of higher strain. The prominent frontal thrust, as described by Escher et al. (197()), is actually formed by an array of sinistral-stepping zones of higher strain. although these cannot be traced across Sukkertoppen lskappe. The investigations showed that the contractional component across most of these zones appears to be more limited than previously assumed.

The investigations in 1994 confirmed that the northern boundary of the SNO corresponds with the northern limit of the Kangâmiut dykes. Metamorphic mineral parageneses in the Kangâmiut dykes show that the southern foreland was alfected by a Nagssugtoqidian static thermal overprint far south of the structural front. Preliminary $P-T$ work on metamorphic Kangâmiut dykes in the SNO has yielded pressures up to 10-12 kbar. The thermal overprint and elevaled pressures may have resulted from loading by large-scale south-directed thrust stacks at levels above the present erosional surface. The tectonic setting and geometry responsible for such a wholesale shortening and loading is not at present completely understood, and further work is being directed towards this problem.

The boundary between the SNO and CNO is an important tectonic (thrust'?) zone where thin, laterally persistent panels of Proterozoic metasediments are tectonically inter- 
leaved with Archaean (2.8-2.7 Ga) granulite lacies gneisses (Figs 1. 2). Similar, c. 2.8-2.7 Ga old gneisses, with a moderately NNW-dipping planar structure, occupy the south-eastern half of the southern CNO. Kinematic indicators in the southern CNO appear mainly to be related (o) sinistral strike-slip movement with a large coaxial thattening component, and the observed lincations are generally subhorizontal to gently dipping. Strike-slip may, however. have overprinted earlier thrust structures as indicated by the interlayering of gneisses and metasediments along the southern margin of the $\mathrm{CNO}$.

The northern part of the southern CNO contains a wide belt of high-grade, anatectic, garnet-sillimanite-bearing metasediments of disputed (possibly Archaean) depositional age and voluminous $c$. 1.93 Ga old orthogneisses. These granulite facies orthogneisses form an ENE-trending magmatic belt and are apparently most abundant in the west, in the Sisimiut areal, where they coincide with an enriched Ba anomaly in the stream sediment geochemistry pattern (A. Steenfelt, pers. comm., 1995). U-Pb studies of detrital and metamorphic zircons in the metasediments are in progress in order to establish their depositional age and provenance. The northern part of the southern CNO with its belt of metasediments and magmatic rocks could tentatively represent the deformed intruded northern edge of the southern Archaean foreland.

The northern $\mathrm{CNO}$ is both lithologically and structurally distinct from the southern CNO. It is characterised by llatlying structures, and consists in the east of 2.8-2.7 Ga Archaean gneisses overlain by sheared Palacoproterozoic marble-bearing metasediments and voluminous 1.93-1.92 (ia meta-yuartz diorites (Fig. 1). The metamorphic grade is granulite facies in the west and amphibolite facies in the east, possibly reflecting a crustal scale eastward tilt, which also readily explains the apparent absence of the metaquart\% diorites in the west. The meta-quart\% diorites have geochemical signatures similar 10 island arc rocks (Kalsbeek et al. 1987) and may have been thrust on top of the Archacan basement gneisses during Nagssugtoyidian collision. Based on geochemical characteristics, the metacuart\% diorites have been interpreted as having developed as a conseguence of subduction and closure of an ocean between two colliding parts of the CNO. In addition, the boundary between the northern and southern $\mathrm{CNO}$ is also recognised as the main dividing line in the regional stream sediment geochemical element pattern, and since most uttramalic bodies of the region seem to be distributed along this line, the boundary is a likely candidate for a Nagssugtoqidian collisional suture.

The lield work in 19994 indicated that an understanding of the evolution of the northern CNO and its boundary relations is essential for establishing and modelling the tectonic evolution of the Nagssugtogidian orogen. Thrusting

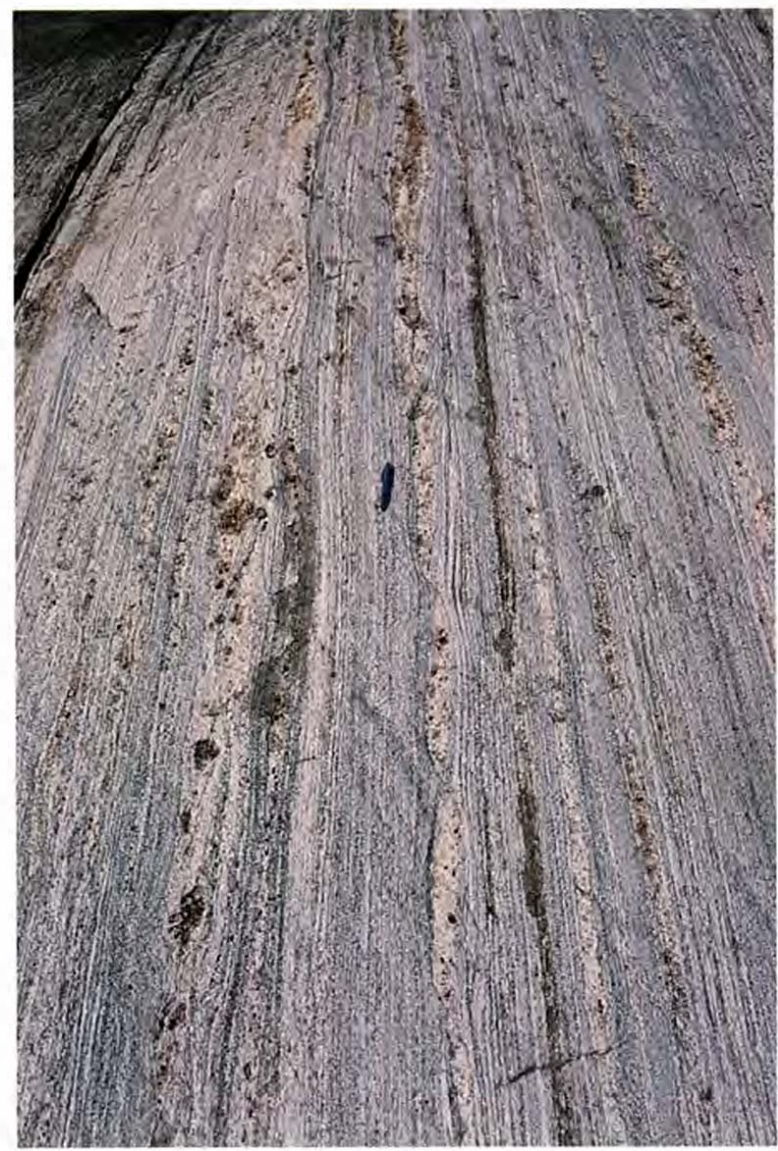

Fig. 3. Highly strained gneisses in the Nordre Stromtjord shear zone. Sinistral shear is shown by the back-rotated pegmatite pods. Pen for sciale.

appears 10 have been substantial in this part of the orogen but the sense and magnitude of movement still remain to be established. A pilot study in the inner part of Arfersionfik indicated that the thrust structure is complex and involves the basement gneisses. A large part of the ficld work in 1995 will address the problems in the CNO.

The NNO consists mainly of uniform Archaean granitic gneisses interpreted to belong to the northern Nagssugt(oyidian foreland. The regional SHRIMP zircon dating programme indicates ages for the granitic gncisses around 2.8-2.7 Ga. These could possibly extend to the south into the northern CNO, where similar ages were obtained, but the role of the intervening Nordre Stromfjord shear zone is not yet clear. This steep belt may include Proterozoic supracrustal rocks, the significance of which also remains to be investigated. The large, crustal-scale sinistral translation inferred in previous studies of the Nordre Stromfjord shear zone (Bak et al. 1975a, b; Sorensen, 1983) could not be confirmed. The lield work showed that the shear zone consists of a belt of steeply dipping gneisses. which 


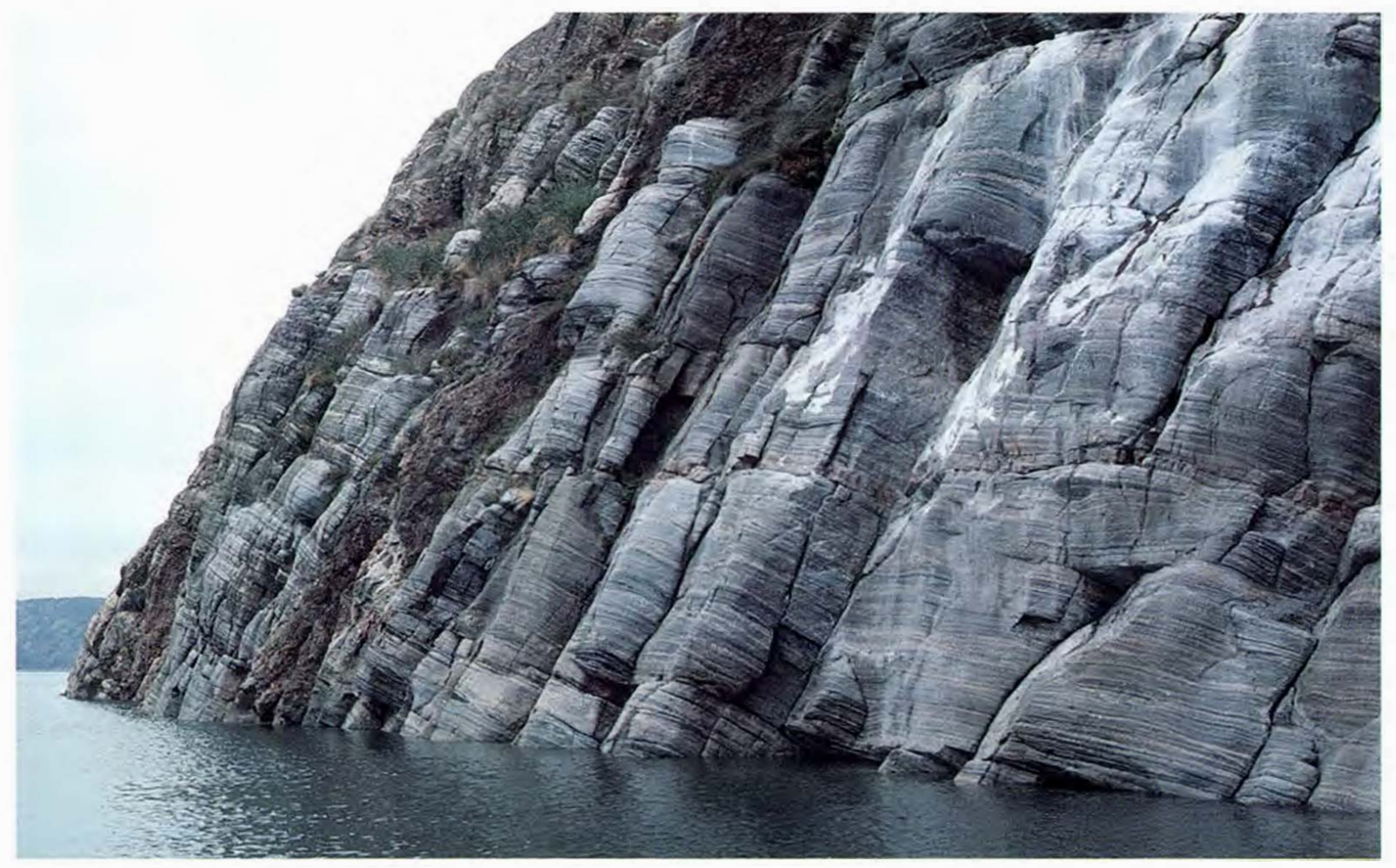

Fig. 4. Gently N-dipping shear zone in the northern part of inner Arfersiortik. The zone is (. 20)() m wide, and can be traced for several kilometres. Rotated porphyroclasts indicate dextral movement. Cliff is approximately $20 \mathrm{~m}$ high.

contain scattered, localised zones of high strain (Fig. I) that are discontinuous and therefore cannot accommodate large displacements. The strain pattern in the steep belt suggests predominantly pure shear with a small. sinistral, non-coaxial component. The age of the structures within the belt is ill-constrained, and the steep gneissic layering may have either an Archaean or a Proterozoic age. The generally sinistral high strain zones are most likely of Proterozoic age, and their overall orientation and kinematic pattern correspond with that of the overall Nagssugtogidian strike-slip pattern.

Preliminary geochronological results indicate a Proterozoic age for the supracrustal rocks at Lersletten (Fig. 1). Therefore the large-scale fold pattern in the supracrustal rocks of the NNO is most likely of Proterozoic age.

From the investigations so far, it is tentatively concluded that the Nagssugtogidian orogen developed through collision of a northern and southern Archaean continent. The evidence for crustal scale convergence comes from the $\mathrm{CNO}$ where igneous island arc suites are found together with evidence of thrusting. The SNO-CNO boundary may also be an important thrust structure. However, the tectonic grain throughout the orogen is dominated by widespread, generally sinistral transpressive strike-slip movement with associated subhorizontal lineations, but without evidence of regionally significant translation. The high strain zones show varying intensity in spacing and thickness and seem to be most dense in the southern CNO and in the ENEtrending steep belt forming the boundary between the CNO and NNO along Nordre Stromfjord (Fig. 1). The transpressive strike-slip geometry indicates that the shear zones formed in response to a NNE-SSW compressive stress field developing a dominant ENE-trending sinistral set (Fig. 3) and a subordinate dextral set trending WNW (Fig. 4). Some larger strike-slip zones in the central CNO are intruded by syn-tectonic granite dated at $c .1 .83-1.85$ Ga, indicating an age for the strike-slip movement.

The continental collision that led to the formation of the Nagssugtoqidian orogen must have occurred somewhat later than the 1.93-1.92 Ga ages obtained from the magmatic igneous suites in the $\mathrm{CNO}$. It is probable that much of the evidence for early thrusting has been structurally and metamorphically overprinted or obliterated by later sinistral strike-slip movements.

Acknowledgements. The DLC ficld party thank the crew of $\mathrm{M} / \mathrm{V}$ Kissanik (Anders, Ellen, Peter and Michalel Pedersen; Mette Grsonlund) for expert seamanship during the investigations in West Greenland. We also acknowledge the kind help provided by M/V Signe West (Poul Burmeister and Kim) during the tirst week of the field work and by Gunnar Hauge Jensen and Bjarne 
Ljungdahl in Sisimiut. Grønlandsfly A/S provided excellent helicopter assistance.

Appendix. 1994 field party in the Nagssugtoqidian orogen: David Bridgwater, Geological Museum, Copenhagen; Andy Cadman, Leicester University, UK; Jim Connelly, University of Texas at Austin, USA; Bjøm Hageskov, Geological Institute, Copenhagen; Simon Hanmer, Geological Survey of Canada, Ottawa, Canada; Feiko Kalsbeek, Geological Survey of Denmark and Greenland, Copenhagen; Leo Kriegsman, University of Utrecht, The Netherlands; Mogens Marker, DLC, Copenhagen; Flemming Mengel, DLC, Copenhagen; Geoff Nichols, California Institute of Technology, Pasadena, USA (now at Maquarie University, Australia); Allen Nutman, Australian National University, Canberra, Australia; Hans Erik Olsen, Geological Institute, Copenhagen; Minik Rosing, Geological Museum, Copenhagen; Jeroen van Gool, DLC, Copenhagen; Martin Whitehouse, University of $\mathrm{Ox}$ ford, UK.

\section{References}

Allaart, J. H. 1982: Geological map of Greenland 1:500 000, Sheet 2, Frederikshåb Isblink - Søndre Strømfjord. Copenhagen: Grønlands Geologiske Undersøgelse.

Bak, J., Korstgård, J. A. \& Sørensen, K. 1975a: A major shear zone within the Nagssugtoqidian of West Greenland. Tectonophysics 27, 191-209.

Bak, J., Sørensen, K., Grocott, J., Korstgård, J. A., Nash, D. \& Watterson, J. 1975b: Tectonic implications of Precambrian shear belts in westem Greenland. Nature 254, 566-569.

Escher, A. 1971: Geological map of Greenland 1:500 000 Sheet 3, Søndre Strømfjord - Nûgssuaq. Copenhagen: Grønlands Geologiske Undersøgelse.

Escher, A., Escher, J. C. \& Watterson, J. 1970: The Nagssugtoqidian boundary and the deformation of the Kangâmiut dyke swarm in the Søndre Strømfjord area. Rapp. Grønlands geol. Unders. 28, 21-23.

Escher, A., Escher, J. C. \& Watterson, J. 1975: The reorientation of the Kangâmiut dyke swarm, West Greenland. Can. J. Earth Sci. 12, 158-173.

Grocott, J. \& Pulvertaft, T. C. R. 1990: The Early Proterozoic Rinkian belt of central West Greenland. In Lewry, J. F. \& Stauffer, M. R. (ed.) The Early Proterozoic Trans-Hudson Orogen of North America. Spec. Pap. Geol. Ass. Can. 37, 443-463.

Kalsbeek, F., Pidgeon, R. T. \& Taylor, P. N. 1987: Nagssugtoqidian mobile belt of West Greenland: cryptic $1850 \mathrm{Ma}$ suture between two Archaean coninents - chemical and isotopic evidence. Earth Planet. Sci. Lett. 85, 365-385.

Olesen, N. Ø., Korstgård, J. A. \& Sørensen, K. 1979: A summary of lithology and structure within the Agto map sheet (67 V.1 Nord), Nagssugtoqidian mobile belt, West Greenland. Rapp. Grønlands geol. Unders. 89, 19-22.

Steenfelt, A., Kalsbeek, F. \& Jepsen, H. F. 1993: Geochemical mapping and geological reconnaissance in the Nagssugtoqidian mobile belt, West Greenland. Rapp. Grønlands geol. Unders. 159, 31-37.

Sørensen, K. 1983: Growth and dynamics of the Nordre Strømfjord shear zone. J. Geophys. Res. 88, 3419-3437.

Thorning, L. 1984: Aeromagnetic maps of parts of southern and central West Greenland: acquisition, compilation and general analysis of data. Rapp. Grønlands geol. Unders. 122, 36 pp.

Thorning, L. 1993: Project AEROMAG-92: a new high resolution aeromagnetic survey of the Lersletten area, central West Greenland $\left(68^{\circ} 15^{\prime}\right.$ to $68^{\circ} 55^{\prime} \mathrm{N}, 50^{\circ} 25^{\prime}$ to $\left.53^{\circ} 35^{\prime} \mathrm{W}\right)$. Open File Ser. Grønlands geol. Unders. 93/2, 34 pp.

M. M., F. M. \& J. v. G., Danish Lithosphere Centre, Øster Voldgade 10, DK-1350 Copenhagen K, Denmark (see also Appendix) 